\title{
Modelling and designing of the system properties based on characteristics and the degree of maturity on the example of a high pressure storage system
}

\author{
Daniel Duschek (M.Eng.) ${ }^{1}$, Prof. Dr.-Ing. Michael Vielhaber ${ }^{2}$ \\ ${ }^{1}$ csi entwicklungstechnik GmbH, Sachsstr. 5, 85080 Gaimersheim, Germany \\ daniel.duschek@csi-online.de \\ ${ }^{2}$ Institute of Engineering Design, Saarland University, 66123 Saarbruecken, Germany \\ vielhaber@lkt.uni-saarland.de
}

\begin{abstract}
The product development process (PDP) in the automotive industry, from design to series production, is a complex process. Increasing customer requirements and growing competition lead to a shortening of the development and innovation cycle of products. The definition of the requirements for new products is of major importance, especially when it comes to new developments, like new powertrain technologies. An extension of the present development procedure and the transformation of customer requirements into technical features and characteristics, is a challenge to be solved by the automobile industry. The consideration of external influences on the product portfolio or product strategy, such as the reduction of the maximum emission rates and the increasing competition in the established sales markets, is of high importance in the development. These require the application of new powertrain technologies. The transformation from traditional drive technologies to electro-mobility requires the integration of new components, like batteries or high-pressure storage systems, into existing platform/module strategies. In order to be able to define the maturity level of the component, e.g. the high-pressure storage, the assembly and the product group, a continuous analysis and synthesis of the features and characteristics is crucial.
\end{abstract}

In this contribution, the relations between features and properties in the development process are based on Weber's Characteristics-Properties Modelling (CPM) approach. A development process is presented which assigns a maturity level and tolerance range to the features of a product / product group as well as the application in a product architecture. This approach allows the most important factors influencing the overall system to be mapped and the system to be optimized on a system level, accordingly. The method is presented based on the knowledge gained from a target- and application-oriented design of pressure storage tanks. Another important aspect is the recording and evaluation of changes in product properties depending on the development phase. The developed method can also be used to record the relationships of a module across platforms and contribute to the formulation of a conflict of objectives.

Keywords: Product development process, product engineering, design automation, simulation, high pressure storage 


\section{Introduction}

The steadily rising customer requirements as well as the increasing limitation of the permissible emission of greenhouse gases presents the automotive industry with a challenge that needs to be solved. By expanding the product portfolio with new powertrain technologies, the required regulations can be achieved. In order to continue on established sales markets and break into new ones, a flexible integration and adaptation of new technologies is also necessary. However, taking these trends into consideration leads to different development times and a varying resulting product maturity of parts/components. In addition to these challenge of rising complexity in the product development, customers expect constant technical progress of the vehicle.

A platform or module strategy is of paramount importance in order to meet both market requirements, especially customer demand, and future approval criteria (Glynn et al., 2010; Hobday, 2000; Schneider \& Rieck, 2012; Schuh et al., 2013). A detailed analysis of the product development process of vehicle platforms and the derivative products shows the high complexity of the product development process (PDP) (Renner, 2007), see figure 1.

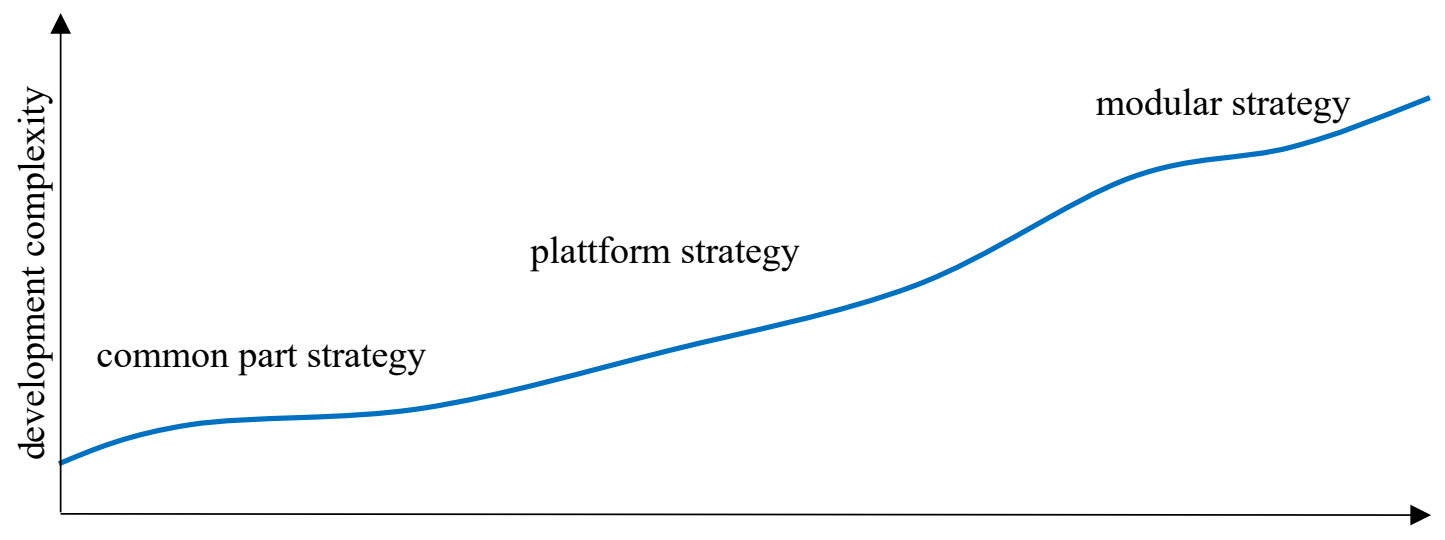

degree of product differentiation

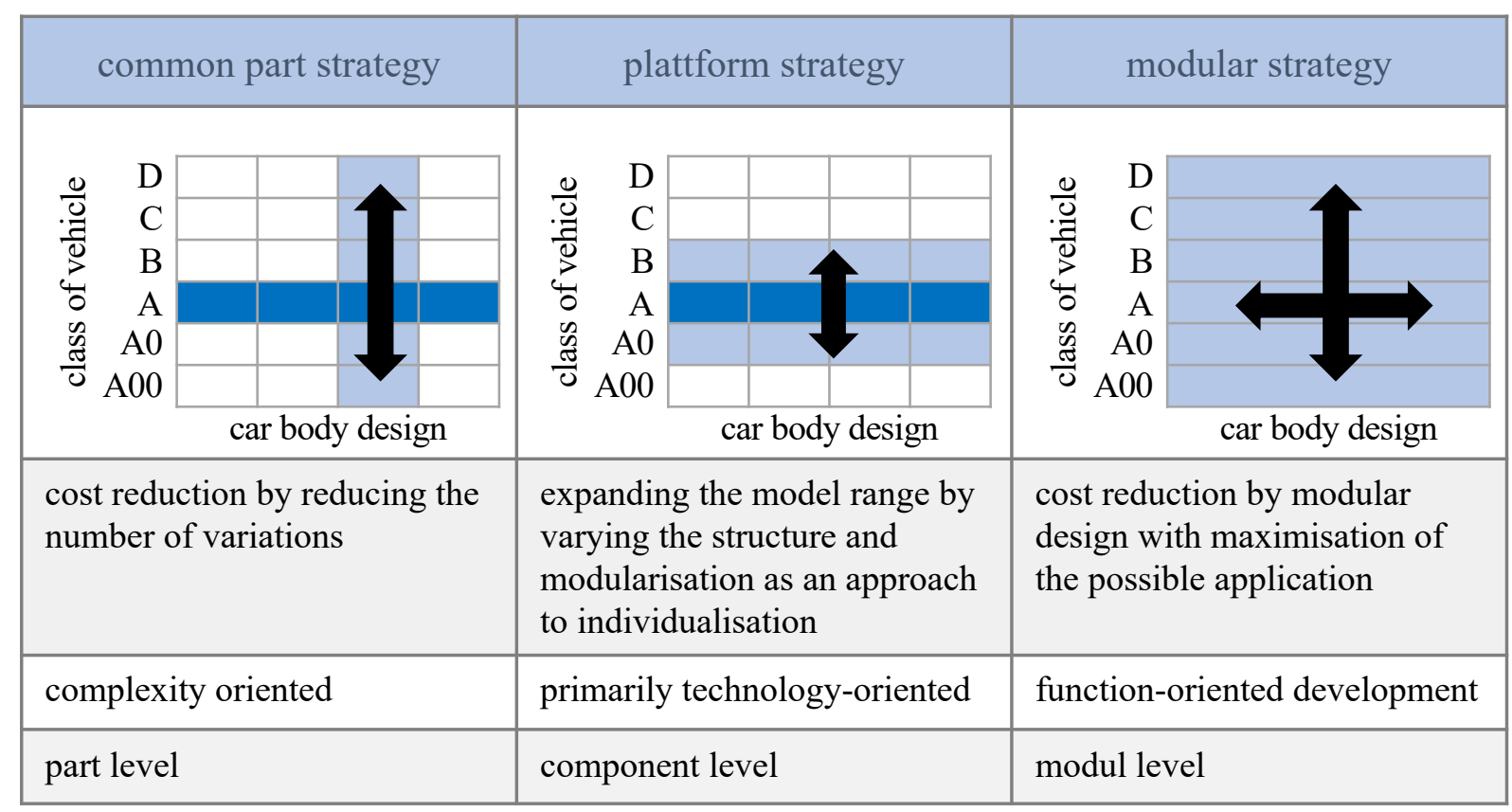

Figure 1. Description of the product strategy of the automotive industry (partially based on Busche, 2014; Hoffmann, 2018; Lemke, 2013; Schuh, G. et al., 2010) 
The modular strategy enables the cross-model implementation of a functional or manufacturing volume with a reduced effort. A further focus is on product and process modules. The target is the formulation and definition of standards, like common parts, in manufacturing, assembly, implementation and testing processes. These measures enable to reduce the costs and development time of a vehicle model, but requires a higher degree of coordination between the respective teams. However, this approach creates relationships and dependencies beyond the individual vehicle models (Ehrlenspiel et al., 2014; Schuh et al., 2013).

In addition, to ensure efficient and effective product development, it is necessary to define the product characteristics and properties as well as the time frame. In this contribution, after defining research questions in chapter 2, a design and evaluation approach of products is realized based on the CPM approach according to Weber in chapter 3. By adding the degree of product maturity, overlapping compounds can be identified. In chapter 4 , the approach is explained in more detail on the example of the integration of a new pressure storage approach. The derived system properties can be evaluated on the basis of valid development targets, such as the DOE targets (DOE, 2009).

\section{Target identification and research questions}

For the product development process, a number of process models and methods exist (Ehrlenspiel \& Meerkamm, 2017; Euringer, 1995; Krause \& Gebhardt, 2018; Lindemann, 2009; Pahl et al., 2013; Ulrich \& Eppinger, 2016; VDI 2221, 1993).These support the analysis of tasks, the generation of solutions and the evaluation of the developed concepts (Lindemann, 2009; Pahl et al., 2013). By using a methodical approach, a development is target-oriented and achieves the desired goals. In the development of new technologies, the analysis of the properties of a system is of great importance.

In the development of high pressure storage tanks, for example, the "development targets", as described in the DOE guidelines for hydrogen applications, are used as evaluation criterion (DOE, 2009). In these documents the system properties, such as volumetric, gravimetric density and the energy density in dependence are defined, see figure 2 "field of action a potential analysis" and "planning development target".

Consequently, a monitoring of the system properties in the PDP development steps (n) is essential. The challenge here is to establish the relationships between features and properties. The extent of the influence can be taken into account by a weighting factor. This contribution targets to detect a modification of properties as a result of external influences on the system of a product and to generate handling recommendations. The formulation of actions enables the developer to implement the necessary changes to elements that are required to achieve the system properties. Therefore, it is necessary to create a relationship of characteristics and properties depending on the time-based PDP sequence, see figure 2. The definition and nomenclature of properties and characteristics is adopted from the Characteristics-Properties Modelling (CPM) / Property-Driven Development/Design (PDD) approach according to Weber (Weber, 2012, 2005; Weber \& Werner, 2000). 


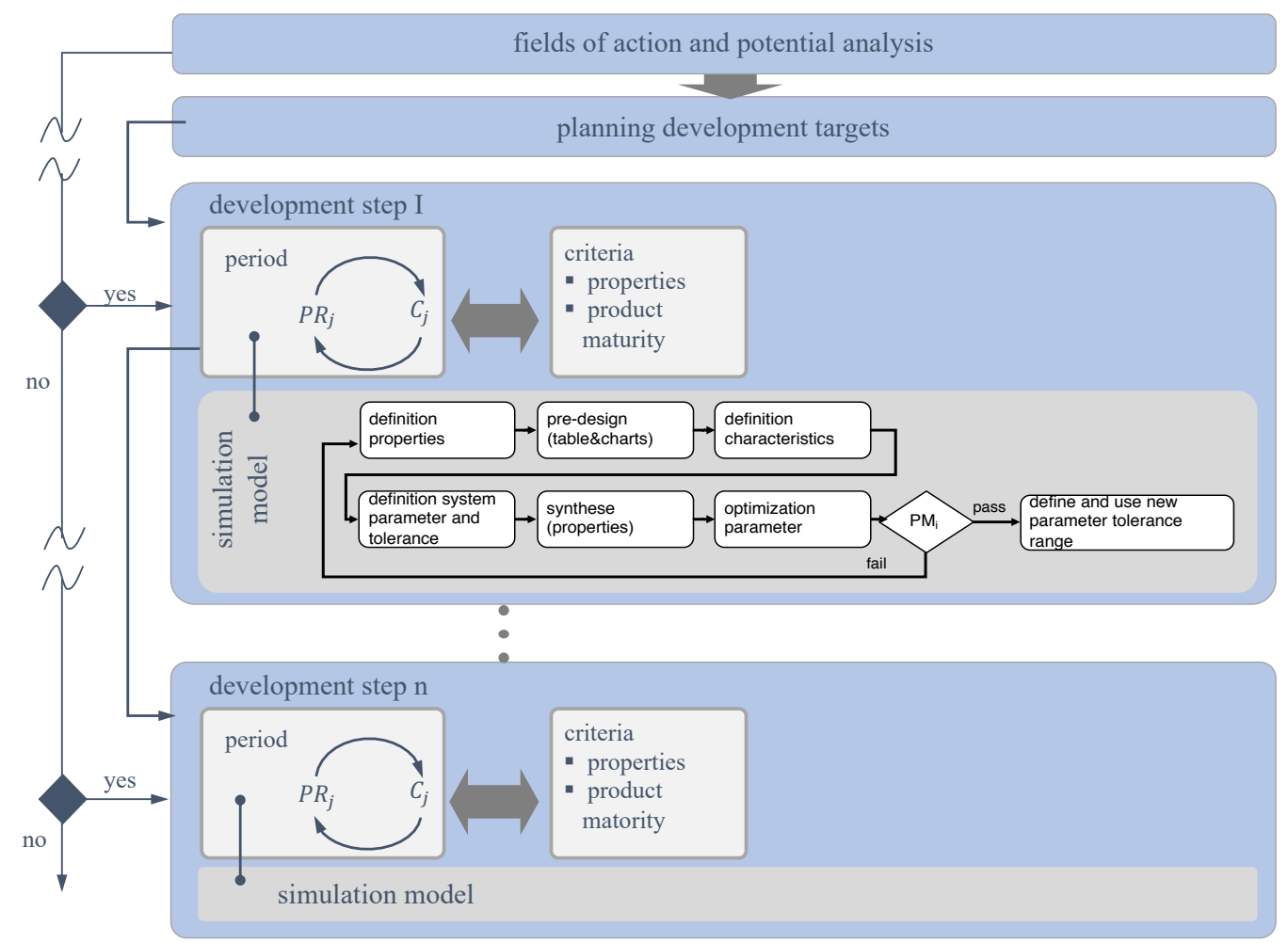

Figure 2. Simulation model of tolerance field and product maturity - based on CPM method

Based on the motivation and target identification, research questions are formulated as follows:

- How can a new technology be integrated in the PDP of conventional module/platform architectures, and how can an evaluation of the system properties be derived?

- What influence has a change of system properties of a main component system for the characteristics of a high-pressure storage module?

- How can a modular and scalable design of a module be developed?

\section{Methodical approach for modelling of the system properties}

The Weber approach describes the modelling and specification of product development processes (Weber, 2012). Characteristics-Properties Modeling (CPM) stands for the product model view and Property-Driven Development (PDD) for the process view. Weber explains a product by its characteristics $(\mathrm{C})$ and properties $(\mathrm{P})$.

The product development methods formulate a sequence of actions in the PDP in different levels of maturity. At the product planning period, the requirements level are high and the characteristics level are low. These are specified in more detail as product development progresses and complexity is reduced by means of a system approach. Based on results and knowledge of past projects, like table and charts, the quality of the characteristics and properties level can be optimized.

Characteristics describe the shape of a product. These are also called "inner properties" and are, in total, the parameters that describe the shape of a technical product or system. The characteristics, also called "external properties", describe the functional requirements and the resulting behaviour of a product. It should be noted that a product developer cannot change the properties directly, only the features. 


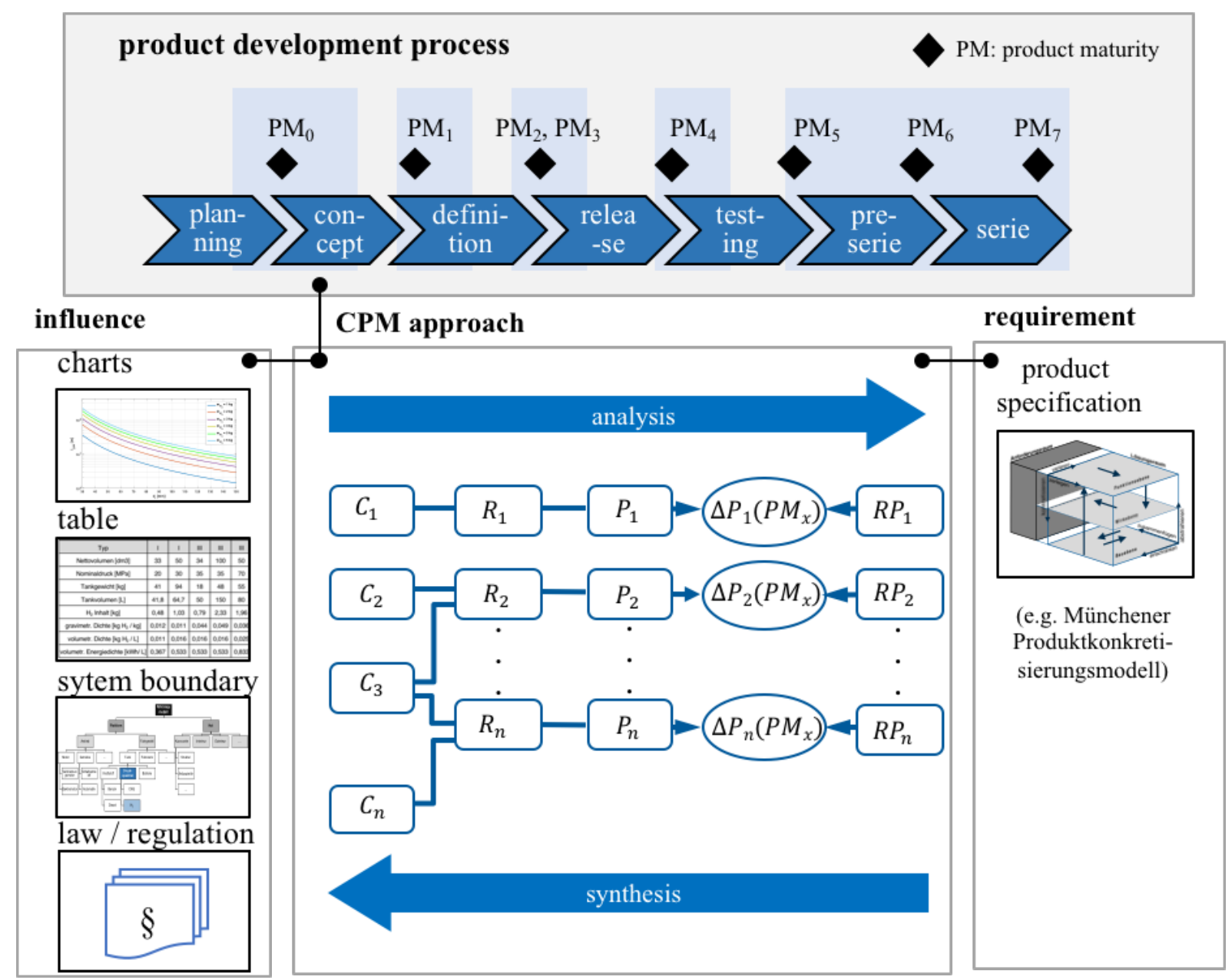

Figure 3. Presentation of the created approach to the maturity-based development of a module, reference to (partially based on Duschek \& Vielhaber, 2018; Lindemann, 2009; Weber, 2012)

By means of analysis and synthesis during the entire development process, the relationships (R) can be monitored. Furthermore, the features and properties are influenced by external conditions. Figure 3 shows the classes of features and properties and the essential relationships between synthesis and analysis. In order to be able to show the progress in the development of components, in dependence of the characteristics, as well as to be able to estimate a possible resulting change of characteristics, the extension of the approach is necessary. The evaluation of component maturity is carried out by means of a maturity management.

The determination of the degree of the product maturity is an important aspect in the product development process. The analysis gives the company an overview of which component can be modified or adapted. In addition, the degree of maturity serves to evaluate the cost-benefit ratio, which must be taken into account when integrating products and technologies. For this purpose, the PM of the components is determined and from this the product maturity level is described. Figure 4 shows the components of a module depending on the degree of the product maturity. This is standardized to the value 1 . The influences of component specifications for the total properties of a module can be defined in more detail by a weighting factor $K$. The criteria for $K$ is the influence of the system properties and function. For example a safety component, like pressure valve is more important as a design part. Carry over or standard parts have the product maturity of 1 . The elements of a hydrogen pressure module are shown in figure 5 . 


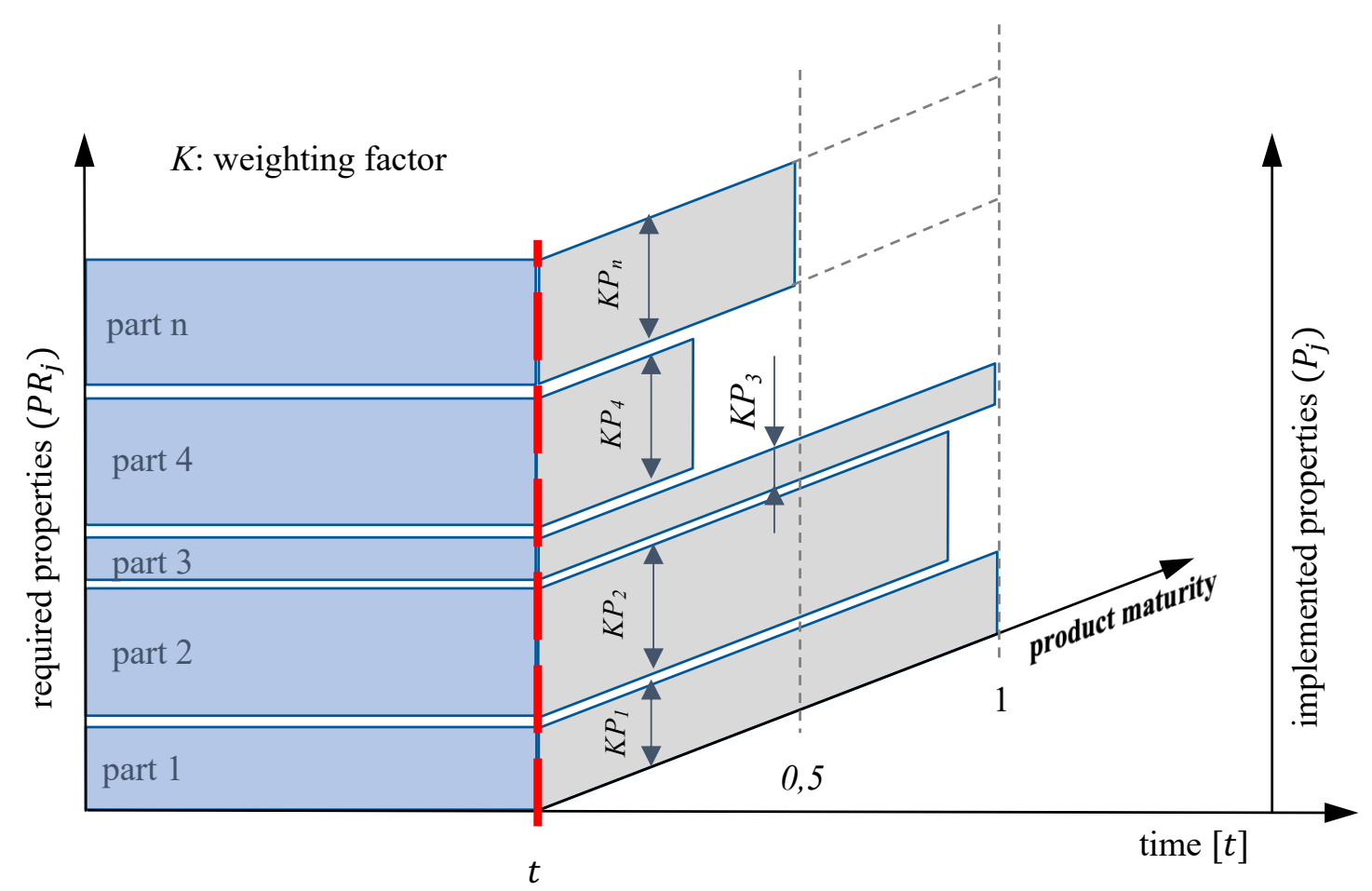

Figure 4. Required and implemented properties - depending on the product maturity

\section{Application and validation of the approach for a hydrogen module}

In the European-funded project "FCCP", 50 fuel cell cargo pedelec pilots are being tested in European cities. At the moment, there are no efficient high-pressure storage systems available for this application. Therefore, the hydrogen tanks are being developed with a new meander shape design. The basis for the product development is the preliminary analyse of commercially tanks, like straight pressure vessels, as well as a patent for curved pressure storage tanks (Duschek, 2017). The challenge is the modular tank design, a scalability depending on the energy requirement and the consideration of safety aspects in the handling of the fuel cell cargo pedelecs in public road traffic. Due to the higher complexity in the development of curved pressure tank, the methodical procedure and the formulation of action sequences is necessary. The design of a curved high-pressure storage is shown in Figure 5.

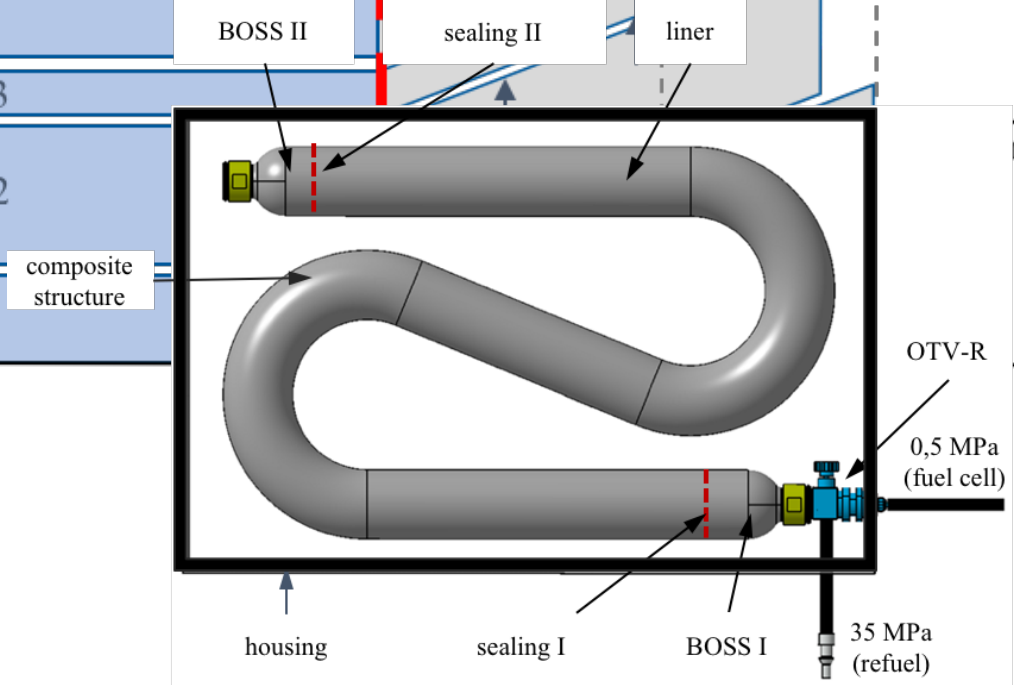

Figure 5. Elements of a hydrogen module (Duschek, 2018; Duschek \& Vielhaber, 2018) 


\subsection{Application of the methodology in the development of the pressure storage module}

The application of the product development method is discussed in more detail on the example of a property change of the storage volume. In the development scenario the representation of the $\mathrm{H}_{2}$ tank in the CPM model is described (see figure 3). In addition, the dependencies within the system boundaries of the product are shown (see figure 5) as well as the effects of the property change on the maturity levels of individual components. Figure 6 shows the parameters for the design of a straight and curved pipe storage tank. The properties of the individual pressure storage tanks are derived from the specified properties (e.g. DOE-targets). The complexity for the curved pipe is greater due to the higher number of variable characteristics. Based on a parameter study, as well as a preliminary analysis of different construction space dimensions, dependencies and relationships between parameters can be formulated. An example is the radius of curvature $r_{b}$ (see figure 6). This radius can be calculated by the bending factor $k_{b}$. This allows a reduction of the number of variable parameters. Another important knowledge from the preliminary research is that the characteristic $d_{i}$ defines the system property significantly. This means that a change of the characteristics $d_{i}$ has an influence on the volumetric and gravimetric energy density.

straight pipe storage design (e.g. type 4)
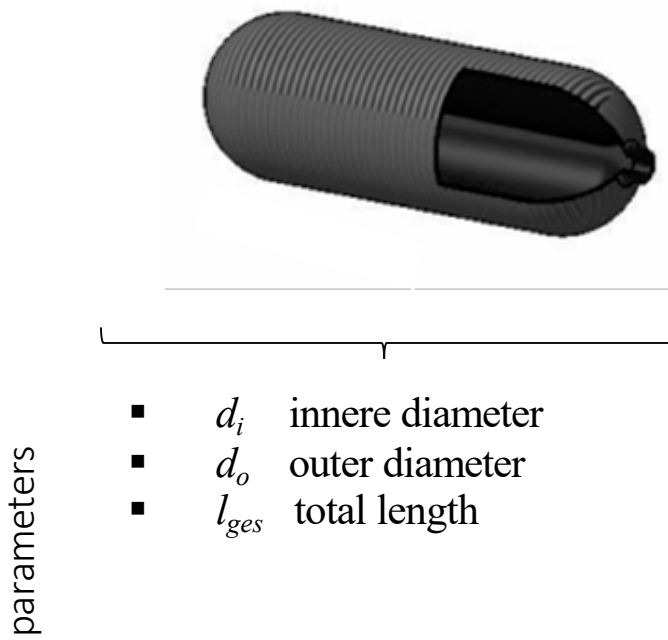

bending pipe storage design

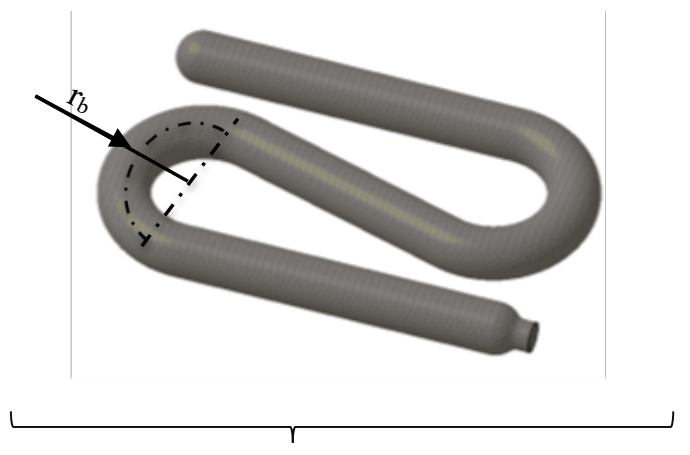

- $d_{i}$ innere diameter

- $d_{o}$ outer diameter

- $k_{b}$ bending factor

- $\quad r_{b}$ bending radius $=k_{b} \cdot d_{i}$

- $\quad l_{\text {ger }}$ length straight pipe

- $\quad l_{g e b}$ length benden pipe

- $l_{\text {ges }}$ total length

- $t_{l} \quad$ wall thickness

- $t_{\text {ges }}$ total wall thickness

Figure 6. Characteristics of a straight and bended hydrogen storage (Duschek et al., 2019)

One possible scenario in the product development process of the fuel cell cargo pedelec is to increase the storage volume by $10 \%$. To reach the targets, the dimensions of the tank and the weight have to be optimized. Both characteristics are limited by the use in cargo bikes. The permissible total weight of the cargo bike is limited by an EU regulation, i.e. the payload decreases with increasing unladen weight of the cargo bike. The available construction space is limited by the bike frame, see figure 7 . 


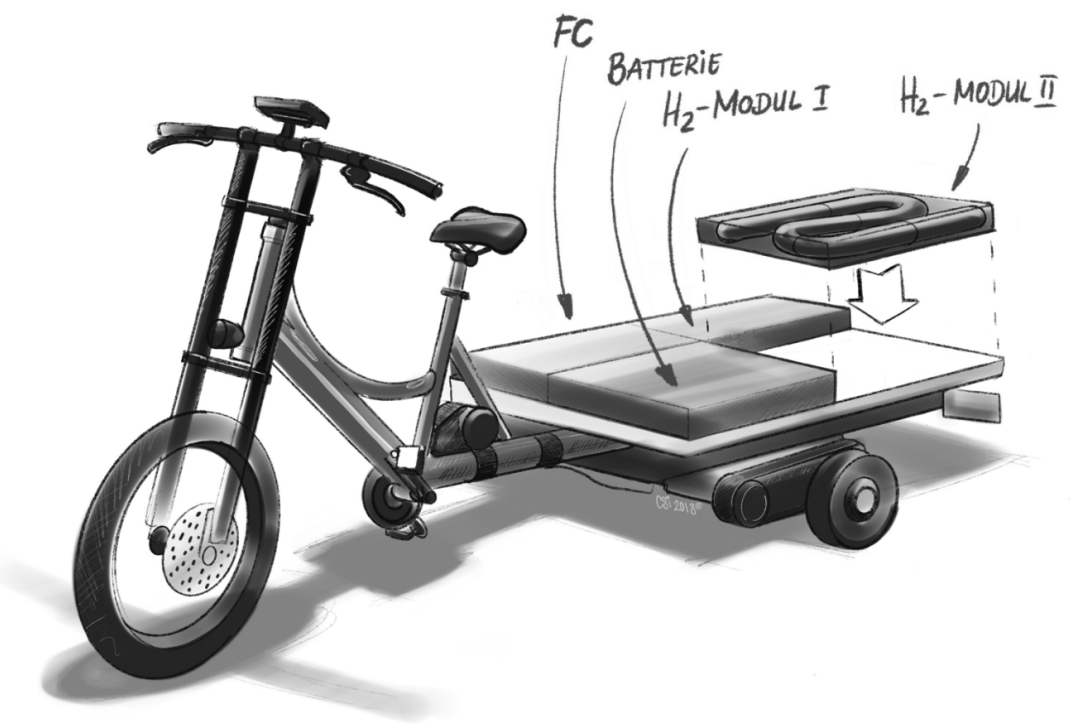

Figure 7. fuel cell cargo pedelec architecture (Duschek, 2018)

The module is integrated into an existing structure. Consequently, an optimization of features such as the diameter can only be realized to a limited extent. A further limitation is the permeation of hydrogen as well as the bursting behaviour. To avoid diffusion of hydrogen, the plastic liner must have a minimum wall thickness of at least three millimetres. Therefore, there is only a possibility of weight adjustment by optimize the wall thickness of thecomposite layer. However, this has an effect on the required operating pressure. Consequently, the load-bearing structure can only be optimized by reducing the diameter or lowering the permissible operating pressure. This change has a direct influence on the storage capacity, volume and gravimetric density. Due to the required energy consumption, this recommended course of action is not target-oriented. Therefore in a further step, the modularity and scaling of the pressure storage system is considered.

An other scenario is, that the frame, in which the pressure storage tank can be integrated has a high degree of maturity for the application, just the height of the module or the number of modules can be adapted. As a result, the characteristic $1_{\text {ges }}$ cannot be modified and the volume of the tank can only be changed using the characteristic $\mathrm{d}_{\mathrm{i}}$.
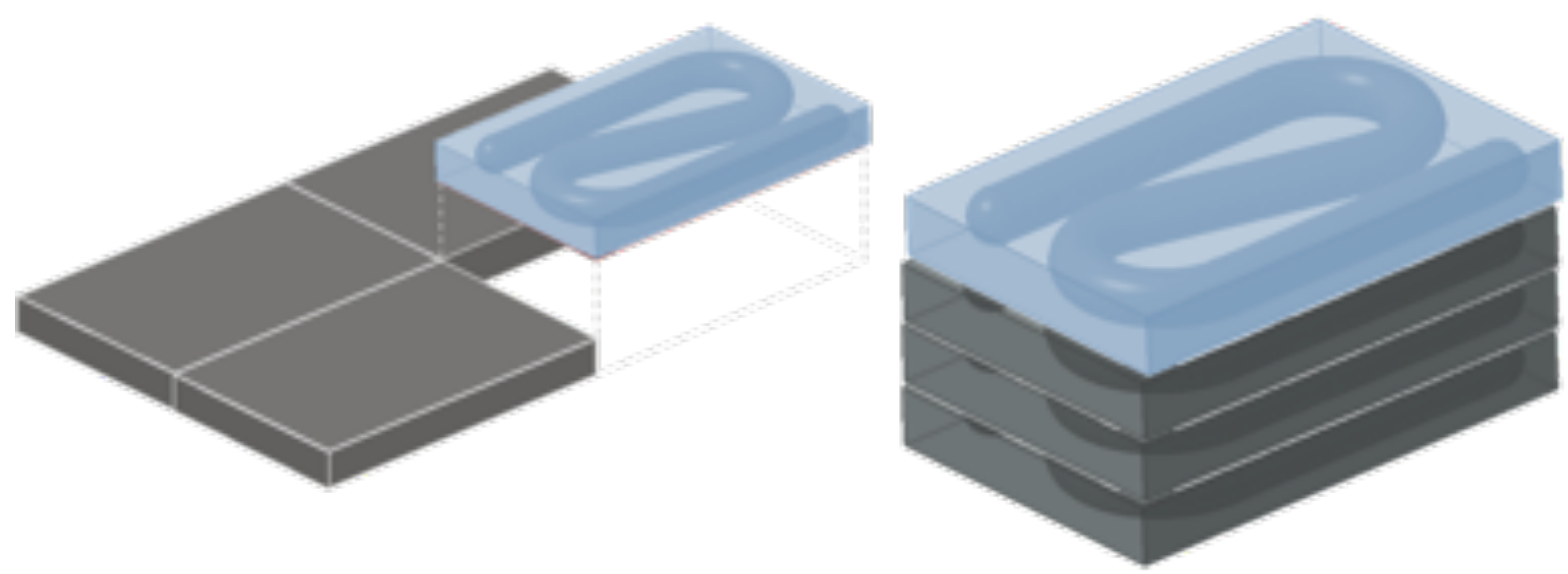

Figure 8. Hydrogen storage module architecture 
Another important aspect is the modular or scalable design of a pressure storage tank. An assembly of $\mathrm{H}_{2}$ modules is to be implemented in the cargo area. The dimensions of the loading area are related to the logistics unit. These dimensions correspond to the dimensions of a Euro pallet, see figure 8 .

The first step is to develop a standardised tank module for this application. The grid size is equivalent to a quarter of a euro pallet. The routing of the pressure tanks is done by fittings (low pressure area). For the assembly of the configuration, the development of an integrated and smart valve is required, which enables the connection of several single tanks. In addition, the housing is customised so that the tanks can be stored safely. Based on the system modification, the new product maturity of the components has to be analysed. By this action, the new maturity level of the component leads to a reduction of the total maturity level of the product changes from $70 \%$ to $50 \%$, see figure. 9 . The reason of the lower product maturity is caused by the modification of the storage guideline. Due to the new design shape, the numerical analyse of the shape stiffness and fluid dynamic have to proofed. It is also necessary to amend the technical specification for production and certification. The housing protects the storage system and the safety distance has to rework, too. From the analysis of the total product maturity, it can be concluded that a new development of the required components for the scalable tank has a large influence on the maturity level. However, an increased added value for the end customer can be achieved here. By formulating the sustainable development goal, the risk is known and the cost-benefit can be evaluated. The modification of a development strategy and the large number of individual components shows the complexity and influences. Based on this knowledge, the created approach and simulation model enable the developer to design an effective module.

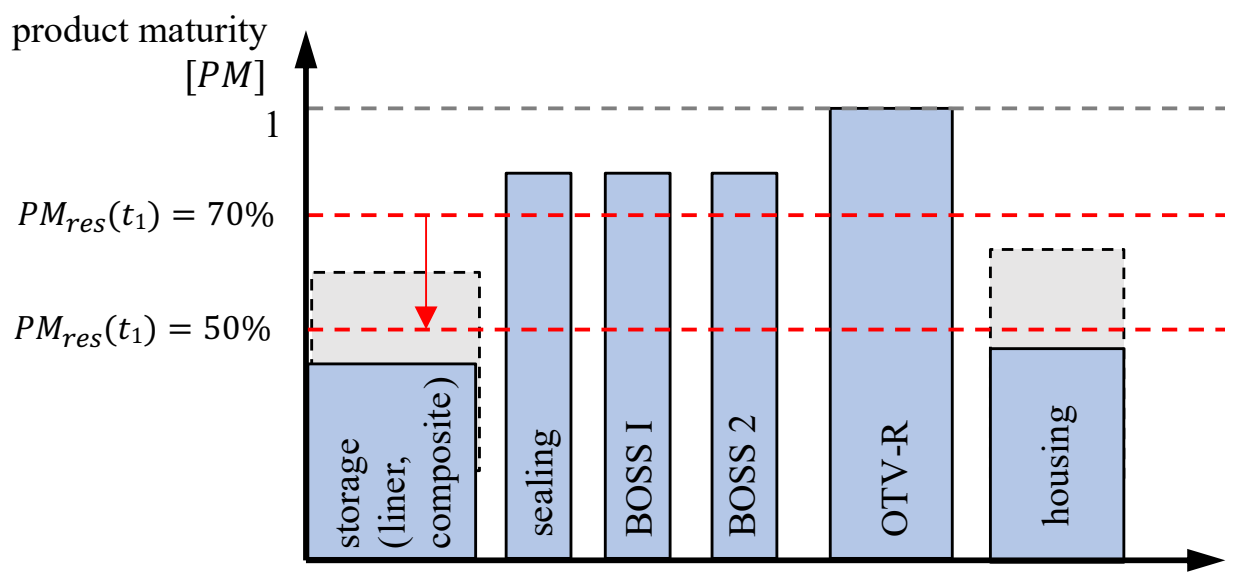

Figure 9. Total degree of maturity for a hydrogen pressure storage tank

\section{Conclusion}

The presented approach is a tool for using by the product developer and designer. The monitoring of system properties during the whole development process enable a high degree of transparency. A market analysis, determination of customer requirements and technology evaluation is the basic for the derivation of recommendations for action. Therefore the development targets are target-, user- and application-oriented. Another important aspect is the existing knowledge and insights of a company and its development partners, because the product development process is sustainable, if the findings from all previous iteration stage are transferred to a subsequent development. Consequently, investment barriers are reduced and the risk for the company during development is minimized. 
The Weber approach is a product development approach. Using the enhancement "Maturity Level", all characteristics and the technical level of readiness required to manufacture the product can be assigned to a component. A challenge is the weighting of the elements of a system considering the influence on the system properties. The resulting definition leads to a weighting of the components and the degree of maturity. The realisation of a function is an important aspect, the components that contribute to the fulfilment of the function receive a higher weighting factor $\mathrm{K}$. The CPM approach can be used to map the internal dependencies. The extended CPM/PDD approach, the maturity level, shows the effects on the product characteristics as a function of the development period that result from the change in characteristics. In this way, the cost-benefit ratio can be determined and sustainable development/progress can be implemented. The sustainable integration of a new technologies is shown on the example "hydrogen storage for cargo pedelec". During the development, the maturity level of the product is described. For this purpose, the degree of maturity of the individual components is detected and monitored and the relevance for the functional fulfilment of the total product is shown. The PM-level can derived from the maturity and the weighting factor of each element. The method is used to analyse the changes in the system properties that can be recognized from the implementation.

\section{Citations and References}

Busche, I. (2014). Ein Beitrag zur optimierten Konzeptauslegung von Fahrzeugen im Bereich der Elektromobilität (Dissertation). Otto-von-Guericke-Universität Magdeburg.

DOE (2009). Targets for Onboard Hydrogen Storage Systems for Light-Duty Vehicles, Revision 4 Edition,

Duschek, D. (2017). Speicherbehälter (Patent No. DE102016110171A1).

Duschek, D. (2018). Wasserstoffspeicherung in der Mirko-Mobilität, 6. Wasserstofftag in Lampoldshausen, WfG Lampoldshausen.

Duschek, D., \& Vielhaber, M. (2018). System simulation of a high-pressure storage depending on the degree of product maturity, In: DS 91: Proceedings of NordDesign 2018, Linköping, Sweden, 14th-17th August 2018 (2018)

Duschek, D., Vielhaber, M., Kornreiter, D., \& Ruppert, M. (2019). Druckspeichersysteme für Wasserstoffanwendungen - Prozess und Modellbildung. FC ${ }^{3}-1$ st Fuel Cell Conference Chemnitz 2019. https://nbn-resolving.org/urn:nbn:de:bsz:ch1-qucosa2-357204

Ehrlenspiel, K., Kiewert, A., Lindemann, U., \& Mörtl, M. A. (Eds.). (2014). Kostengünstig Entwickeln und Konstruieren: Kostenmanagement bei der integrierten Produktentwicklung (7. Aufl). Springer Vieweg.

Ehrlenspiel, K., \& Meerkamm, H. (2017). Integrierte Produktentwicklung: Denkabläufe, Methodeneinsatz, Zusammenarbeit (6., vollständig überarbeitete und erweiterte Auflage).

Euringer, C. (1995). Marktorientierte Produktentwicklung: Die Interaktion zwischen F\&E und Marketing. Dt. Univ.-Verl. [u.a.].

Glynn, M. A., Kazanjian, R., \& Drazin, R. (2010). Fostering innovation in complex product development settings: The role of team member identity and interteam interdependence. Journal of Product Innovation Management, 27(7), 1082-1095.

Hobday, M. (2000). The project-based organisation: An ideal form for managing complex products and systems? Research Policy, 29(7-8), 871-893.

Hoffmann, C.-A. (2018). Methodik zur Steuerung modularer Produktbaukästen (Dissertation). Springer. 
Krause, D., \& Gebhardt, N. (2018). Methodische Entwicklung modularer Produktfamilien: Hohe Produktvielfalt beherrschbar entwickeln. Springer Vieweg.

Lemke, H. (2013). Die Modul-Baukasten-Strategie des Volkswagen Konzerns im Zusammenspiel mit globalen Systemlieferanten. http://www.rkw-bw.de/rde/pdf/RKWOrganisation-2013/Vortrag-Lemke-VW.pdf

Lindemann, U. (2009). Methodische Entwicklung technischer Produkte: Methoden flexibel und situationsgerecht anwenden (3., korrigierte Aufl). Springer.

Pahl, G., Beitz, W., Feldhusen, J., \& Grote, K.-H. (Eds.). (2013). Konstruktionslehre: Methoden und Anwendung erfolgreicher Produktentwicklung (8., vollständig überarbeitete Auflage). Springer Vieweg.

Renner, I. (2007). Methodische Unterstützung funktionsorientierter Baukastenentwicklung am Beispiel Automobil (Dissertation). 1. Aufl. Hut Verlag.

Schneider, R. A., \& Rieck, K. (2012). Komplexität in der Automobilindustrie am Beispiel Baukastenstrategie. In U. Goltz, M. Magnor, H.-J. Appelrath, H. K. Matthies, W.-T. Balke, \& L. Wolf (Eds.), INFORMATIK 2012 (pp. 863-872). Gesellschaft für Informatik e.V.

Schuh, G., Krumm, S., \& Amann, W. (2013). Chefsache Komplexität. Springer Fachmedien Wiesbaden. https://doi.org/10.1007/978-3-658-01614-2

Schuh, G., Lenders, M., Arnoscht, J., \& Rudolf, S. (2010). Effizienter innovieren mit Produktbaukästen Studienergebnisse und Leitfaden-Ein Beitrag zu Lean-Innovation. WZL.

Ulrich, K. T., \& Eppinger, S. D. (2016). Product design and development (Sixth edition). McGraw-Hill Education.

VDI 2221. (1993). VDI 2221-Methodik zum Entwicklen und Konstruieren technischer Systeme und Produkte. VDI Verlag.

Weber, C. (2012). Looking at "DFX" and "Product Maturity" from the Perspective of a New Approach to Modelling Product and Product Development Processes. In Krause, D., Paetzold, K., \& Wartzack, S. (Eds.), Beiträge zum 23. DfX-Symposium. Hamburg, TUtech, 2012.

Weber, C. (2005). CPM/PDD-an extended theoretical approach to modelling products and product development processes. Proceedings of the 2nd German-Israeli Symposium on Advances in Methods and Systems for Development of Products and Processes, 6.

Weber, C., \& Werner, H. (2000). Klassifizierung von CAX-Werkzeugen für die Produktentwicklung auf der Basis eines neuartigen Produkt- und Prozessmodells. Schnaittach. 11. Symposium "Design to X". 